\title{
PENGARUH KOMUNIKASI DAN KEBIJAKAN UU ITE TERHADAP TINDAK PIDANA PENIPUAN JUAL BELI BARANG ONLINE DI INSTAGRAM
}

\author{
Erni Yusnita Siregar, Muhammad Sulaiman \\ STAIN Mandailing Natal \\ Email: erni10.yusnitasiregar@gmail.com
}

\begin{abstract}
In the internet media, the crime that often occurs is fraud on behalf of the buying and selling business using the internet media that offers a variety of sales products. There are many cases where when the money has been sent by the buyer, the goods that should have been sent by the seller were not sent or the goods sent were different which did not match the information provided by the seller. Therefore, legal action is needed to provide a deterrent effect on the online buying and selling fraudsters. This research was conducted to determine how the influence of communication and policy of the ITE Law on the criminal act of buying and selling goods online on Instagram using a normative juridical approach to critically analyze criminal law norms against the criminal act of buying and selling goods online on Instagram. The method used in this research is normative. The data source obtained is secondary data. The results of this study discuss legal policies against criminal acts that regulate consumer protection.
\end{abstract}

\section{Keywords: Communication, ITE Law Policy, Online Fraud}

\section{Abstrak}

Dalam media internet, kejahatan yang sering terjadi adalah penipuan dengan mengatas namakan bisnis jual beli dengan menggunakan media internet yang menawarkan berbagai macam produk penjualan. Banyak kasus dimana saat uang sudah dikirim oleh si pembeli, barang yang 
seharusnya dikirim oleh si penjual tidak dikirim atau barang yang dikirim berbeda tidak sesuai informasi yang diberikan oleh si penjual. Oleh sebab itu dibutuhkan Tindakan hukum untuk memberikan efek jera terhadap para penipu jual beli online tersebut. Penelitian ini dilakukan untuk mengetahui tentang bagaimana pengaruh komunikasi dan kebijakan UU ITE terhadap tindak pidana penipuan jual beli barang online di Instagram dengan pendekatan yuridis normatif untuk menganalisis secara kritis norma hukum pidana terhadap tindak pidana penipuan jual beli barang online di Instagram. Metode yang digunakan dalam penelitian ini adalah normatif. Sumber data yang didapat adalah data sekunder. Hasil penelitian ini membahas kebijakan hukum terhadap tindak pidana yang mengatur perlindungan konsumen.

\section{Kata Kunci: Komunikasi, Kebijakan UU ITE, Penipuan Online}

\section{Pendahuluan}

Internet sebagai suatu media dan komunikasi elektronik telah banyak di manfaatkan, salah satunya adalah melakukan perdagangan. Dalam media internet, kejahatan yang sering terjadi adalah penipuan dengan mengatas namakan bisnis jual beli dengan menggunakan media internet yang menawarkan berbagai macam produk penjualan khususnya handphone dan barang elektronik yang dijual dibawah harga rata-rata. Kasus-kasus yang muncul di permukaan dan diketahui oleh publik umumnya berdasarkan adanya laporan dari korban cyber crime akan kerugian yang dialaminya. Banyak kasus dimana saat uang sudah dikirim oleh si pembeli, barang yang seharusnya dikirim oleh si penjual tidak dikirim atau barang yang dikirim berbeda tidak sesuai informasi yang diberikan oleh si penjual. Oleh sebab itu dibutuhkan Tindakan hukum untuk memberikan efek jera terhadap para penipu jual beli online tersebut. $^{1}$

${ }^{1}$ Safiranita, Tasya. 2017. Aspek Hukum Transaksi Perdagangan Melalui Media Elektronik Dikaitkan dengan Undang-Undang Nomor 19 Tahun 2016 tentang Informasi 
Perkembangan media sekarang ini berkembang pesat dari tahun ke tahun. Berawal dari media konvensional hingga akhirnya di era digital ini media sosial menjadi media paling populer di kalangan masyarakat modern. Media sosial di berbagai platform memudahkan penggunanya dalam melakukan komunikasi bahkan dalam jangkauan yang lebih luas lewat berbagai aplikasi yang disuguhkan seperti Instagram. Menurut survei data Asosiasi Penyelenggara Jasa Internet Indonesia (APJII) terakhir di tahun 2016, pengguna internet di Indonesia mencapai 132,7 juta dan media sosial Instagram menjadi media sosial populer kedua dengan jumlah pengguna mencapai 19,9 juta atau 15 persen (www.apjii.or.id). Di era digital ini, dalam memenuhi kebutuhan masyarakat akan berita, salah satu media sosial seperti Instagram sekarang ini juga dimanfaatkan oleh berbagai media untuk menyebarkan berita, bisa dengan video singkat atau mengunggah foto dan juga memberi caption (keterangan foto) (kompasiana.com). ${ }^{2}$

Kegiatan perdagangan dengan memanfaatkan internet atau media online atau yang sering kita sebut dengan istilah e-commerce (electronic commerce) saat ini merupakan bagian dari perubahan pola interaksi masyarakat. Di satu sisi, perdagangan secara online memilliki dampak positif pada pemenuhan kebutuhan manusia karena perdagangan secara online dapat mengefektifkan dan mengefisiensikan waktu dimana seseorang dapat melakukan transaksi jual beli dengan setiap orang dimanapun dan kapanpun tanpa melakukan tatap muka antara para pihak. Mereka mendasarkan transaksi jual beli tersebut atas rasa kepercayaan. Akan tetapi disisi lain juga dirasakan dampak negatif dari transaksi secara online karena penjual dan pembeli tidak bertatap muka atau berinteraksi secara langsung maka kemungkinan barang/ jasa

dan Transaksi Elektronik, Jurnal Fakultas Hukum, Dialogia luridica, ISSN: 2085-9945 | eISSN: 2579-3520 Volume 8 Nomor 2, April 2017, : 15-23

${ }^{2}$ https://www.kompasiana.com/bencha/59d0da972ba8d16a6211c7f2/peran-mediasosial instagram-dalam-penyebaran-berita. Diakses 26 April 2020 
yang diterima tidak sesuai dengan yang diinginkan atau jumlah uang yang diterima penjual juga tidak sesuai atau bahkan tidak mendapat sama sekali pembayaran yang diinginkan. Oleh karenanya hak atas informasi dalam transaksi berbasis transaksi elektronik menjadi penting dalam implementasinya.

Berdasarkan penjelasan tersebut diambil rumusan masalah, yaitu Bagaimana pengaruh komunikasi terhadap ke penipuan jual beli online dan Bagaimana perlindungan hukum terhadap konsumen dalam kebijakan UU ITE.

Dalam penjelasan diatas tujuan dari penulisan ini adalah untuk Menganalisis Pengaruh Komunikasi dan Kebijakan UU ITE Terhadap Tindak Pidana Penipuan Jual Beli Barang Online di Instagram.

\section{Kerangka Teori}

Komunikasi mengandung makna bersama-sama (Common). Istilah komunikasi berasal dari Bahasa latin yaitu Communicatio yang berarti pemberitahuan atau pertukaran kata sifat nya communis yang bermakna umum atau Bersama - sama. Sarah Trenholm dan Arthur Jensen (1996: 24 ) mendefinisikan komunikasi demikian: "A Process by which a source transmit a message to a receiver though some channel." Komunikasi adalah suatu proses dimana sumber mentransmisi pesan kepada penerima melalui beragam saluran (Wiryanto: 2004). ${ }^{3}$ Secara umum, pengertian komunikasi adalah suatu aktivitas penyampaian informasi, baik itu pesan, ide, dan gagasan, dari satu pihak ke pihak lainnya. Biasanya aktivitas komunikasi ini dilakukan secara verbal atau lisan sehingga memudahkan kedua belah pihak untuk saling mengerti. Sementara itu, komunikasi terjadi tidak tanpa melalui sebuah proses. Proses komunikasi biasanya dimulai dengan adanya bahan pembicaraan yang dilontarkan oleh pembicara yang kemudian diterima oleh penerima (liputan6.com).

\footnotetext{
${ }^{3}$ Wiryanto, 2004, Pengantar Ilmu Komunikasi. (Jakarta: Grasindo), hlm 5-6
} 
Beberapa ahli memiliki pendapat berbeda tentang proses terjadinya komunikasi. Model komunikasi Aristoteles merupakan model komunikasi pertama dan merupakan model komunikasi yang diterima secara luas diantara model komunikasi lainnya. Model ini memiliki lima elemen, yaitu speaker, speech, occasion, audience, dan effect. Aristoteles menitikberatkan pada pembicara (speaker) dan bicara (speech) karena pembicara dipandang sebagai pihak yang aktif dan berperan penting dalam proses public speaking yaitu mengirimkan pesan kepada khalayak. Dalam model ini, khalayak digambarkan bersifat pasif dalam menerima pesan. Oleh karena itu, proses komunikasi dalam model Aristoteles berlangsung secara satu arah atau linier yakni dari pengirim ke penerima. Proses komunikasi menurut Aristoteles dimulai dari pembicara (speaker) yang mengutarakan pesan (speech) dalam suatu situasi (occasion) kepada khalayak (audience) yang kemudian menimbulkan dampak atau pengaruh (liputan6.com). ${ }^{4}$

Dalam Undang-Undang Nomor 11 Tahun 2008 tentang Informasi dan Transaksi Elektronik ("UU ITE”) sebagaimana telah diubah oleh Undang-Undang Nomor 19 Tahun $2016^{5}$ tentang Perubahan Atas Undang-Undang Nomor 11 Tahun 2008 tentang Informasi dan Transaksi Elektronik (“UU 19/2016") tidak secara khusus mengatur mengenai tindak pidana penipuan. Selama ini, tindak pidana penipuan sendiri diatur dalam Pasal 378 Kitab Undang-Undang Hukum Pidana (KUHP), dengan rumusan pasal sebagai berikut: Barangsiapa dengan maksud untuk menguntungkan diri sendiri atau orang lain secara melawan hukum dengan menggunakan nama palsu atau martabat (hoedaningheid) palsu; dengan tipu muslihat, ataupun rangkaian kebohongan, menggerakkan orang lain untuk menyerahkan barang sesuatu kepadanya, atau supaya memberi utang maupun menghapuskan piutang, diancam, karena

\footnotetext{
${ }^{4}$ https://www.liputan6.com/citizen6/read/3877665/proses-komunikasi-dan pengertiannya-menurut-para-ahli. Diakses 26 April 2020

${ }^{5}$ UU No 11 Tahun 2008 tentang Informasi dan Transaksi Elektronik
} 
penipuan, dengan pidana penjara paling lama empat tahun (Hukumonline.com).

Walaupun UU ITE dan perubahannya tidak secara khusus mengatur mengenai tindak pidana penipuan, namun terkait dengan timbulnya kerugian konsumen dalam transaksi elektronik terdapat ketentuan Pasal 28 ayat (1) UU ITE jo. Pasal 45 A ayat (1) UU 19/2016. Setiap Orang dengan sengaja, dan tanpa hak menyebarkan berita bohong dan menyesatkan yang mengakibatkan kerugian konsumen dalam Transaksi Elektronik. Adapun sanksi pidana jika melanggar Pasal 28 ayat (1) UU ITE diatur dalam Pasal 45A ayat (1) UU 19/2016, yaitu: Setiap Orang yang dengan sengaja dan tanpa hak menyebarkan berita bohong dan menyesatkan yang mengakibatkan kerugian konsumen dalam Transaksi Elektronik sebagaimana dimaksud dalam Pasal 28 ayat (1) dipidana dengan pidana penjara paling lama 6 (enam) tahun dan/atau denda paling banyak Rp 1.000.000.000,00 (satu miliar rupiah) (Hukumonline.com). ${ }^{6}$

Pengaruh komunikasi merupakan cara seseorang untuk berbaur dan memudahkan sesuatu maupun tujuan dalam hal ini seperti Instagram merupakan media penghubung seseorang berkomunikasi untuk melakukan perkenalan maupun bisnis yang berkembang dan memberikan kemudahan dalam berbelanja komunikasi pihak-pihak yang hendak melakukan transaksi tidak harus bertatap muka, namun dapat dilakukan dalam kondisi masing-masing di tempat yang berbeda, termasuk di Indonesia. Berbicara mengenai keabsahan suatu transaksi secara elektronik, maka pertama-tama harus ditegaskan terlebih dahulu dasar hukum dari transaksi termaksud. Transaksi secara elektronik lahir berdasarkan asas kebebasan berkontrak sebagaimana telah diatur dalam Pasal 1338 ayat (1) BW, yang mana setiap orang bebas untuk

\footnotetext{
${ }^{6} \mathrm{https}: / /$ www.hukumonline.com/klinik/detail/ulasan/lt5d1ad428d8fa3/cara menentukan pasal-untuk-menjerat-pelaku-penipuan-online/. Diakses 26 April 2020
} 
menentukan bentuk, macam dan isi perjanjian/ perikatan asalkan tetap memenuhi syaratsyarat sahnya perjanjian sesuai ketentuan Pasal 1320 BW, tidak melanggar ketertiban umum dan kesusilaan, sehingga setiap perjanjian yang dibuat oleh para pihak menjadi undang-undang bagi pihakpihak yang membuatnya. Begitu pula dalam transaksi secara elektronik, pihak- pihak yang terlibat dalam transaksi itu merupakan subjek hukum, baik orang maupun badan hukum bebas melakukan perikatan dengan bentuk, cara serta isi yang ditentukan berdasarkan kesepakatan pihak-pihak tersebut, dalam hal ini para pihak melakukan perikatan berupa transaksi melalui media internet dengan isi perjanjian yang disepakati para pihak melalui internet pula, jadi mereka saling berhubungan melalui media internet. (Hetty Hassanah:2015) ${ }^{7}$

Menurut ketentuan Pasal 1320 BW, syarat sahnya suatu perjanjian terdiri dari: a. Kesepakatan para pihak b. Kecakapan para pihak c. Suatu hal tertentu d. Suatu sebab yang halal Kesepakatan para pihak maksudnya harus ada persesuaian kehendak antara para pihak yang membuat perjanjian baik diungkapkan secara tegas maupun diam-diam. Apabila kesepakatan timbul karena adanya paksaan, kekhilafan atau kekeliruan maka perjanjian dapat dibatalkan artinya perjanjian masih berlaku sampai dibatalkan oleh hakim atas permintaan para pihak, dengan demikian kesepakatan ini merupakan salah satu syarat subjektif untuk sahnya perjanjian. (Hetty Hassanah:2015). Komunikasi yang saling sepakat dan sepemikiran inilah yang menjadikan transaksi ini berkelanjutan berbekal rasa percaya tidak jarang muncul seseorang dengan secara sengaja melakukan penipuan melalui media internet yaitu Instagram, tidak jarang komunikasi dengan perkembangan teknologi ini

${ }^{7}$ Hetty, H. (2015). Analisis Hukum Tentang Perbuatan Melawan Hukum Dalam Transaksi Bisnis Secara Online (E-Commerce) Berdasarkan Burgerlijke Wetboek Dan Undang-undang Nomor 11 Tahun 2008 Tentang Informasi Dan Transaksi Elektronik. Jurnal Wawasan Hukum, Vol. 32, No.1, Februari 2015 
menimbulkan korban yang sangat banyak dari suatu harga yang menggiurkan dan barang - barang yang sangat baik.

\section{Metode Penelitian}

Penelitian ini merupakan penelitian hukum normatif dengan pendekatan yuridis normatif untuk menganalisis secara kritis norma hukum pidana terhadap tindak pidana penipuan jual beli barang online di Instagram. Data yang digunakan adalah data sekunder meliputi bahan hukum primer yang terdiri dari Hukum Nasional: Undang-Undang Dasar Negara Republik Indonesia Tahun 1945, Kitab UndangUndang Hukum Pidana (KUHP), Kitab UndangUndang Hukum Acara Pidana (KUHAP), UndangUndang Nomor 19 Tahun 2016 tentang Perubahan atas UndangUndang Nomor 11 Tahun 2008 tentang Informasi dan Transaksi Elektronik serta peraturan perundang-undangan lainnya. Disamping itu juga digunakan bahan hukum sekunder yang meliputi pendapat para ahli hukum pidana yang termuat dalam literatur, jurnal maupun artikel baik dalam bentuk cetakan maupun dalam bentuk elektronik. Selain itu kajian meliputi kamus hukum dan ensiklopedia hukum tentang penipuan Jual beli barang online di Instagram. Data yang diperoleh melalui studi kepustakaan kemudian dianalisis dengan metode analisis kualitatif dengan penguraian secara deskriptif (pemaparan). ${ }^{8}$

\section{Hasil Penelitian dan pembahasan}

\section{A. Pengaruh Komunikasi terhadap tindak penipuan jual beli barang online di Instagram}

Pengaruh komunikasi sangat berpengaruh dalam Transaksi jual Beli komunikasi ini merupakan Langkah awal seseorang dalam memulai sesuatu perjanjian dan membuat kesepakatan dengan maksud

${ }^{8}$ Rahmanto, Toni Yuri. (2019). Penegakan Hukum Terhadap Tindak Pidana Penipuan Berbasis Transaksi Elektronik, Jurnal Penelitian Hukum, DE JURE, e-ISSN 2579-8561, Vol. 19 No. 1, Maret 2019: hlm 36-38 
tertentu,dengan komunikasi inilah peran seseorang penjual dan pembeli menawarkan beberapa barang dan jenis harga yang menggiurkan misalnya harga yang di tawarkan jauh lebih dari harga pasaran dan produk pembelian bonus beli satu gratis satu komunikasii yang meyakinkan dan bujuk rayu menjadikan seseorang dengan mudah mempengaruhi pembeli yang sudah merasa dekat dan yakin dalam hal ini perlu adanya upaya atau langkahhukum untuk memberikan penegakkan keadilan guna memberikan rasa aman dan menjamin kepastian hukum terhadap si penjual dan si pembeli dalam melakukan jual beli di instagram Pada dasarnya, Transaksi Elektronik merupakan suatu model kontrak yang sama dengan kontrak jual beli konvensional yang dilakukan masyarakat pada umumnya.

Jual beli secara konvensional yang dilakukan oleh masyarakat hingga saat ini dilakukan berdasarkan ketentuan yang diatur di dalam $\mathrm{KUH}$ Perdata. Oleh karena tidak jauh berbeda dengan perjanjian jual beli konvensional, maka asas-asas umum dalam perjanjian seperti asas kebebasan berkontrak, asas konsensualisme, asas pacta sunt servanda, dan juga asas itikad baik juga berlaku dalam Transaksi Elektronik. Asas kebebasan berkontrak artinya setiap orang bebas membuat perjanjian yang terdapat dalam undang-undang yang dikenal sebagai perjanjian bernama, misalnya jual beli, sewa menyewa, tukar menukar. Asas kebebasan berkontrak ini didasarkan pada ketentuan menentukan: "Semua perjanjian yang dibuat secara sah berlaku sebagai undangundang bagi mereka yang membuatnya." Asas Konsensualisme, artinya dengan adanya kata sepakat antara kedua belah pihak, perjanjian sudah mengikat. Berdasarkan asas konsensualisme, perjanjian dianggap ada bersamaan dengan timbulnya kesepakatan untuk melakukan suatu perikatan terhadap asas konsensualisme ini terdapat pengecualian, yakni 
adanya perjanjian riil, misalnya: (a) Perjanjian penitipan barang; (b) Perjanjian pinjam pakai dan; (c) Perjanjian pinjam pakai sampai habis. ${ }^{9}$

\section{B. Kebijakan UU ITE terhadap tindak pidana penipuan jual beli barang online di Instagram}

Pengaturan hukum sangat penting terhadap penipuan yang dilakukan secara online untuk melindungi masyarakat yang melakukan transaksi online. Masyarakat yang melakukan transaksi online dan mengalami penipuan dapat menimbulkan kerugian secara materil dan dapat menguntungkan pihak yang melakukan kejahatan. Penipuan ini bertujuan untuk mencari keuntungan pribadi dengan menggunakan perangkat lunak. Dengan meningkatnya jumlah peningkatan terhadap internet kejahatan semakin meningkat mengikuti perkembangan dari tekhnologi ini sendiri. Semakin banyak kejahatan dan pihak yang dirugikan apabila tidak adanya ketersediaan hukum yang mengaturnya.

Sebelum adanya Undang-undang ITE aparat hukum menggunakan KUHP $^{10}$ dalam menangani kasus-kasus tindak kejahatan Transaksi Online. Ketentuan yang terdapat dalam KUHP masih bersifat global. Tindak pidana yang diatur dalam Undang-Undang ITE yaitu Undangundang Nomor 19 Tahun 2016 tentang perubahan atas Undang-undang 11 Tahun 2008 tentang informasi dan transaksi elektronik (ITE) tidak secara langsung mengatur mengenai tindak pidana penipuan secara online. Dalam hal ini tidak ada pasal pasal penipuan didalamnya tetapi ada pengaturan yang melarang menyebarkan berita bohongan yang dapat merugikan konsumen, yaitu pada pasal 28 ayat (1) UU ITE yang mengatakan bahwa :"setiap orang dengan sengaja, dan tanpa hak menyebarkan berita bohong dan menyesatkan yang mengakibatkan kerugian konsumen dalam transaksi elektronik".Sesuai dengan ketentuan Pasal 45 ayat (2) UU No.11 Tahun 2008, ditetapkan bahwa "setiap orang

\footnotetext{
${ }^{9}$ Ibid, hlm. 40

${ }^{10}$ Kitab Undang-undang Hukum Pidana (KUHP)
} 
yang memenuhi unsur sebagaimana dimaksud dalam Pasal 28 ayat (1) atau ayat (2) dipidana dengan pidana penjara paling lama 6 (enam) tahun dan/atau denda paling banyak Rp1.000.000.000,00 (satu miliar rupiah)".Terkait dengan tindak pidana penipuan, antara KUHP dan UU ITE terdapat perbedaan, yaitu rumusan Pasal 28 ayat (1) UU ITE tidak mensyaratkan adanya unsur "menguntungkan diri sendiri atau orang lain" sebagaimana diatur dalam Pasal 378 KUHP tentang penipuan. Akan tetapi kedua pasal ini memiliki kesamaan yaitu tentang akibat yang timbul oleh tindak pidana penipuan yang dapat merugikan orang lain. Dari pihak kepolisian bisa saja menggunakan pasal-pasal berlapis mengenai suatu perbuatan penipuan, termasuk tindak pidana penipuan yang diatur dalam pasal 378 KUHP dan pasal 28 ayat (1) UU ITE. Adanya peraturan perundang-undangan yang mengatur tentang ITE dapat menguntungkan bagi konsumen. UU ITE yang disahkan sebagai Undang-undang Nomor 19 Tahun 2016 tentang perubahan atas Undang-undang Nomor 11 Tahun 2008 dapat meminimalisir dan melindungi hak-hak konsumen dari kejahatan melalui media elektronik dan media online. ${ }^{11}$

\section{Penegakan Hukum Terhadap Tindak Pidana Penipuan}

Dalam pembelian jual-beli barang yang melalui media online terdapat suatu perjanjian jual-beli, sehingga menerbitkan suatu perikatan, yaitu perikatan yang bersumber dari perjanjian atau sering disebut dengan perjanjian bernama, Jual-beli melalui media online seharusnya mengikuti peraturan yang ada Salah satu jenis transaksi jual beli melalui online yang saat ini banyak digunakan adalah melalui instagram, facebook dan toko jual beli online seperti Zalora, shopee. Setiap transaksi perdagangan terdapat risiko \& permasalahan,keliru satu kasus yang dihadapi yaitu Ketika konsumen merasa dirugikan lantaran barang yang dibeli tidak diterimanya, sebagai akibatnya beliau mengadukan bahwa beliau tertipu

${ }^{11}$ Undang-undang Nomor 19 Tahun 2016 Tentang Perubahan Atas Undangundang Nomor 11 Tahun 2008 Tentang Informasi Dan Transaksi Elektronik. 
sang toko online yang memakai akun facebook. Kasus lain yang terjadi pada jual beli online yaitu konsumen membeli barang tetapi sesudah barang diterima tidak sinkron menggunakan yang diperjanjikan.

Untuk itu dalam hal ini diperlukan penegakan hukum terhadap tindak pidana penipuan atas jual beli barang online tersebut. Abdul kadir Muhammad berpendapat ${ }^{12}$ bahwa penegakan hukum dapat dirumuskan sebagai usaha melaksanakan hukum sebagaimana mestinya, mengawasi pelaksanaanya agar tidak terjadi pelanggaran, dan jika terjadi pelanggaran memulihkan hukum yang dilanggar itu supaya ditegakkan kembali". Kemudian Jimly Asshidiqie $^{13}$ membagi dua pengertian penegakan hukum yaitu dalam arti sempit merupakan "kegiatan penindakan terhadap setiap pelanggaran atau penyimpangan terhadap peraturan perundang-undangan melalui proses peradilan pidana yang melibatkan peran aparat kepolisian, kejaksaan, advokat atau pengacara dan badan-badan peradilan. Sementara dalam arti luas merupakan kegiatan untuk melaksanakan dan menerapkan hukum serta melakukan tindakan hukum terhadap setiap pelanggaran hukum yang dilakukan oleh subjek hukum baik melalui prosedur peradilan ataupun melalui prosedur arbitrase dan mekanisme penyelesaian sengketa lainnya (alternative disputes or conflict resolution)".

Selanjutnya dalam kaitannya dengan hukum pidana, pada dasarnya hukum pidana merupakan hukum yang bersifat publik dimana di dalam hukum pidana tersebut terkandung aturan-aturan yang menentukan perbuatan-perbuatan yang tidak boleh dilakukan dengan disertai ancaman berupa pidana dan menentukan syarat-syarat pidana dapat dijatuhkan dan penggunaan hukum pidana dalam mengatur masyarakat pada hakekatnya merupakan bagian dari suatu langkah penegakan hukum sehingga dapat

\footnotetext{
${ }^{12}$ Abdulkadir Muhammad, Etika Profesi Hukum (Bandung: PT. Citra Aditya Bakti, 2006).

${ }^{13}$ Asshidiqie, Jimly. Hukum Tata Negara Dan Pilar-Pilar Demokrasi, Serpihan Pemikiran Hukum, Media Dan HAM. Jakarta: Konstitusi Press dan PT. Syaamil Cipta Media, 2006.
} 
dipahami bahwa penegakan hukum pidana merupakan upaya untuk tegaknya atau berfungsinya norma-norma hukum secara nyata sebagai pedoman perilaku dalam lalu lintas atau hubungan hubungan hukum dalam kehidupan bermasyarakat dan bernegara. Ditinjau dari sudut subyeknya, penegakan hukum pidana dapat dilakukan oleh subyek yang luas dan dapat pula diartikan sebagai upaya penegakan hukum yang melibatkan semua subyek.

Tidak hanya penipuan dengan jumlah besar saja tetapi penipuan dengan jumlah yang kecil juga sering terjadi akan tetapi konsumen lebih serring membiarkan saja dan tidak melapor karena nominal yang sedikit tidak membuat mereka mengalami kerugian besar beda halnya jika terjadi kepada pedagang yang kecil yang ingin melapor tetapi kerugian yang sedikit padahal mengenai penipuan online dalam Undang-undang nomor 11 tahun 2008 tentang Informasi dan Transaksi Elektronik tidak ada pengaturannya secara eksplisit, yang diatur dalam Undang-undang ITE adalah penyebaran beritaa bohong yang menyesatkan yang mengakibatkan kerugian konsumen dalam transaksi elektronik.

\section{Kesimpulan}

Berdasarkan pembahasan terhadap penelitian sebagaimana dikemukakan dapat ditarik kesimpulan bahwa Kebijakan hukum pidana dalam transaksi jual beli online telah diatur secara jelas dalam UndangUndang No. 11 Tahun 2008 Tentang Informasi dan Transaksi Elektronik dan KUHP. Secara khusus perlindungan hukum konsumen dalam transaksi elektronik terdapat pada pasal 28 ayat (1) UU ITE. Perbuatan sebagaimana sudah dijelaskan dalam pasal tersebut ancaman pidana penjara sesuai dengan ketentuan terdapat pada pasal 45 ayat (2) UU ITE dengan ancaman pidana paling lama 6 (enam) tahun dan/atau denda paling banyak Rp 1 Miliar .

Perlindungan hukum pada Undang-Undang No. 11 Tahun 2008 Tentang Informasi dan Transaksi Elektronik dan Pasal 378 KUHP. Dan 
sanksi sudah dijelaskan dalam pasal 45 ayat (2) UU ITE serta pembuktiannya penegak hukum bisa menggunakan bukti elektronik dan/atau hasil cetakan sebagai perluasan bukti ada pada pasal 5 ayat (2) Undang-Undang No. 19 Tahun 2016 Tentang Perubahan atas UU Nomor 11 Tahun 2008 Tentang Informasi dan Transaksi Elektronik disamping bukti konvensial lainnya sesuai dengan Kitab Undang-Undang Hukum Acara Pidana. Selain UU ITE dan KUHP pasal 378 Penipuan juga terdapat pada pasal $379 \mathrm{KUHP}^{14}$ yang menjelaskan berapa jumlah kerugian yang dapat dilaporkan dan dapat dibedakan apakah tindak pidana tersebut penipuan atau penipuan ringan. Namun keraguan konsumen serta mahalnya biaya perkara daripada kerugian dan minimnya pengetahuan konsumen terhadap hukum yang berlaku dan tidak mengerti atau tidak tahu apa yang seharusnya mereka lakukan jika mereka tidak mendapatkan hak-haknya.

Berdasarkan prinsip transaksi secara online biasanya dari beberapa pihak lebih mengedepankan aspek kepercayaan atau "trust" terhadap penjual maupun pembeli. Prinsip keamanan transaksi secara online ini belum menjadi perhatian utama apalagi transaksi yang dilakukan dalam skala kecil maupun medium dengan nominal transaksi yang kurang seberapa atau tidak terlalu besar. Salah satu penyebab banyaknya transaksi penipuan ini melalui media online/internet atau media telekomunikasi lainnya. Dengan banyaknya penipuan yang telah terjadi, akan lebih baiknya apabila selektif lagi dalam melakukan transaksi online dan lebih berhati-hati agar mengurangi adanya penipuan, sebagai pertimbangan jika nantinya akan melakukan transaksi jual-beli secara online.

${ }^{14}$ 379a KUHP: barangsiapa membuat pencahariannya atau kebiasaannya membeli barang-barang dengan maksud supaya ia sendiri atau orang lain mendapat barang-barang itu dengan tidak melunaskan sama sekali pembayarannya, dihukum penjara selama-lamanya empat tahun. 


\section{DAFTAR PUSTAKA}

Abdulkadir Muhammad, Etika Profesi Hukum (Bandung: PT. Citra Aditya Bakti, 2006).

Asshidiqie, Jimly. Hukum Tata Negara Dan Pilar-Pilar Demokrasi, Serpihan Pemikiran Hukum, Media Dan HAM. Jakarta: Konstitusi Press dan PT. Syaamil Cipta Media, 2006.

Hetty, H. (2015). Analisis Hukum Tentang Perbuatan Melawan Hukum Dalam Transaksi Bisnis Secara Online (E-Commerce) Berdasarkan Burgerlijke Wetboek Dan Undang-undang Nomor 11 Tahun 2008 Tentang Informasi Dan Transaksi Elektronik. Jurnal Wawasan Hukum, Vol. 32, No.1, Februari 2015

https://www.hukumonline.com//linik/detail/ulasan/t5d1ad428d8fa3/caramenentukan-pasal-untuk-menjerat-pelaku-penipuan-online/.

Diakses 26 April 2020

https://www.kompasiana.com/bencha/59d0da972ba8d16a6211c7f2/peranmedia-sosial-instagram-dalam-penyebaran-berita. Diakses 26 April 2020

https://www.liputan6.com/citizen6/read/3877665/proses-komunikasi-danpengertiannya-menurut-para-ahli. Diakses 26 April 2020

Jimly Asshidiqie, Hukum Tata Negara dan Pilar-Pilar Demokrasi, Serpihan

Pemikiran Hukum, Media dan HAM (Jakarta: Konstitusi Press dan

PT. Syaamil Cipta Media, 2006).

Rahmanto, Toni Yuri. (2019). Penegakan Hukum Terhadap Tindak Pidana Penipuan Berbasis Transaksi Elektronik, Jurnal Penelitian Hukum, DE JURE, e-ISSN 2579-8561, Vol. 19 No. 1, Maret 2019: 31-52. Safiranita, Tasya. 2017. Aspek Hukum Transaksi Perdagangan Melalui Media Elektronik Dikaitkan dengan Undang-Undang Nomor 19 Tahun 2016 tentang Informasi dan Transaksi Elektronik, Jurnal Fakultas Hukum, Dialogia luridica, ISSN: 2085-9945 | e-ISSN: 2579-3520 Volume 8 Nomor 2, April 2017, : 15-23 
UU No 11 Tahun 2008 tentang Informasi dan Transaksi Elektronik Undang-undang Nomor 8 Tahun 1999 Tentang Perlindungan Konsumen. Undang-undang Nomor 19 Tahun 2016 Tentang Perubahan Atas Undangundang Nomor 11 Tahun 2008 Tentang Informasi Dan Transaksi Elektronik.

Wiryanto, 2004, Pengantar IImu Komunikasi. (Jakarta: Grasindo) 